\title{
The May 2012 Emilia (Italy) earthquakes: preliminary interpretations on the seismogenic source and the origin of the coseismic ground effects
}

\author{
Alberto Pizzi ${ }^{\star}$, Vittorio Scisciani
}

Università di Chieti-Pescara 'G. d'Annunzio', Dipartimento di Ingegneria e Geologia, Chieti, Italy

\author{
Article history \\ Received July 27, 2012; accepted August 31, 2012. \\ Subject classification: \\ Seismic methods, Earthquake geology and paleoseismology, Structural geology, Earthquake source and dynamics, Tectonics.
}

\section{Introduction}

On May 20, 2012, a $\mathrm{M}_{\mathrm{L}} 5.9$ earthquake (T1) occurred in the Emilia-Romagna Region of northern Italy. This was preceded by a $M_{L} 4.1$ foreshock on May 19, 2012, and followed by several aftershocks, including two $\mathrm{M}_{\mathrm{L}} 5.1$ events, both on the same day. On May 29, 2012, a second strong event of $\mathrm{M}_{\mathrm{L}} 5.8$ (T2) hit the same region, with its epicenter ca. $12 \mathrm{~km}$ to the WSW of the first mainshock, T1.

The epicentral area of the seismic sequence covers an alluvial lowland that is occupied by both agricultural and urbanized areas, and there were 17 casualties and about 14,000 people left homeless. For both of the mainshocks, the focal mechanism solutions indicate low-angle reverse faulting with ca. WNW-ESE-trending ruptures that originated at a depth of $6.3 \mathrm{~km}$ for the T1, and $10.2 \mathrm{~km}$ for T2 (ISIDe, http: / / iside. rm.ingv.it). These events occurred along the ca. E-W-striking outermost active sector of the northern Apennines thrust front that is currently buried by a thick Miocene-Quaternary foredeep and thrust-top siliciclastic succession (mainly turbidites and alluvial deposits) that fill the basin of the Po Plain. The presence of seismogenic thrust structures was already known for this area, based on historical seismicity records, subsurface geological data, and geomorphological observations [Burrato et al. 2003, CPTI Working Group 2011, DISS Working Group 2010, Scrocca et al. 2007]. However, the occurrence of the 2012 seismic events provided new input for the characterization of the seismogenic sources and gave rise to new questions. For example, the occurrence of two close events in space and time of similar magnitude raise the need to further understand the relationships between the two seismogenic sources at depth (single segmented fault, or two faults).

Geological surveys soon after a mainshock can provide crucial information about the occurrence (or absence) at the surface of coseismic deformation features either of primary (i.e., surface faulting) and/ or of secondary (created by seismic shaking) origin. Although the magnitude of the two mainshocks (5.9 and 5.8) were just above the magnitude limit of surface-faulting earthquakes [e.g., Wells and Coppersmith 1994], several reports, as well as the present study, have indicated the absence of surface faulting (i.e., blind faulting). In contrast, extensive evidence of secondary effects were reported, which were mostly represented by earthquake-induced liquefaction features [e.g., Report DPC_1 2012, Report Regione Emilia Romagna and DPC 2012, and other reports available on-line]. Although not spatially associated with coseismic surface faulting, liquefaction distribution can provide important information about liquefaction hazard assessment for future earthquakes, in terms of maximum distance estimation of expected liquefaction effects, once the potential seismogenic source and its expected magnitude and liquefaction susceptibility at the epicentral area are known [e.g., Obermeier 1996, Galli 2000]. Furthermore, the magnitude threshold for producing liquefaction (i.e., 5.0-5.5) is similar to the magnitude threshold for producing significant earthquake damage. In Italy, indeed, several dense populated areas next to seismogenic sources with potential magnitudes $\geq$ ca. 5.0 lie on sediments with moderate to high liquefaction susceptibility [Galli 2000, DISS Working Group 2010]. Moreover, field observations of liquefaction distribution can contribute to better definition of the magnitude/farthest liquefaction distance relationships used for magnitude estimation in paleoseismological studies [Obermeier 1996, Galli 2000].

In the present study, we provide a preliminary model of the seismogenic source(s) responsible for the two mainshocks, by comparing the seismic reflection profile interpretation with the available seismological and interferometric data. Furthermore, we show the coseismic ground effects that were observed in the epicentral area during two field survey campaigns: the first conducted after the May 20, 2012, event and the second soon after the May 29, 2012, earthquake, when several sites were revisited to observe the occurrence of newly formed or 're-activated' liquefaction 
features. Hence, we discuss the origin and location of the coseismic features observed in the context of the local geological-geomorphological setting and with respect to the epicentral distance. Finally, we provide our interpretation for the question: "Why did the mainshock ruptures not break the surface?"

\section{Tectonic and structural setting}

The Emilia 2012 seismic sequence activated the buried central sector of the northern Apennine outer thrust fronts. This arc-shaped part of the Apennines is composed of several $\mathrm{N}(\mathrm{NE})$-verging compressive structures (mainly folds and blind thrusts), which developed in the Miocene-Quaternary foredeep basin of the Po Plain - north Adriatic.

The basin infill consists of Quaternary near-shore/continental deposits and siliciclastic Neogene hemipelagic, foredeep and shallow-water sediments resting on top of the Mesozoic passive margin succession, which is mainly composed of carbonates, with Triassic dolomites and evaporites at the base. The top of the carbonate sequence generally corresponds to the upper part of the pelagic Scaglia Fm. or to the shallow-water carbonates of the Bagnolo Fm., which is limited to the SW part of the study area [Fantoni and Franciosi 2010]. The main facies and thickness variations of the Po basin sedimentary infill mainly derive from the foredeep fragmentation operated by the syn-sedimentary growth of thrust related folds, which has been active from Messinian to present times [Ghielmi et al. 2010, and references therein]. The Quaternary activity of the compressive structures is testified by geological [Regione Emilia Romagna and Eni-Agip 1988, Boccaletti et al. 1985, Scrocca et al. 2007, Toscani et al. 2009], geomorphological [Burrato et al. 2003], geodetic [Devoti et al. 2011], and seismological [DISS Working Group 2010, CPTI Working Group 2011] data. Moreover, borehole breakouts from deep wells and stress inversions from focal mechanism solutions [Montone et al 2012] indicate that $\mathrm{Sh}_{\max }$ trends near perpendicular to the attitude of the thrust faults in the subsurface.

\section{Preliminary interpretation of the seismogenic sources}

The Emilia-Romagna seismic sequence affected an area that is characterized by three major buried structural highs that are delimited to the south by the so-called 'Pedeapenninic Thrust Front', as defined by Boccaletti et al. [1985]. The WNW-ESE striking Occhiobello-Ficarolo anticline represents the northernmost ridge, which is a north-verging thrust-related anticline, and is delimited to the south by a minor back-thrust. The displacement achieved by the southdipping thrust (Figure 1a, b, Th1) is low and the fault remains blind at depth. Towards the south, a prominent ridge runs from Ferrara-Bondeno to immediately south of Poggio Rusco, and this strongly deforms and uplifts the entire siliciclastic and carbonate succession. In the western sector, two near-parallel anticlines that trend WNW-ESE comprise the structural high. The northern anticline is buried and limited to the south by a shallow back-thrust (Figure 1a, b), and it affects the Quaternary sediments, as suggested by the interpretation of seismic reflection profiles. The second thrust-related anticline (Figure 1a, b, Th3) clearly truncates and deforms the shallow siliciclastic succession, including the Quaternary strata, and disappears to the east of Finale Emilia. The thrust fault shows low displacement near to the top of the carbonate succession and gently dips towards the hinterland (Figure 1a, b, Th3). However, at a depth of more than $5 \mathrm{~km}$, the continuity of the thrust is unclear on the seismic profiles, possibly due to interference with the innermost and more complex structure corresponding to the CavoneMirandola-San Felice sul Panaro structural high. In the western sector, this latter structure is arc-shaped in the map view, and shows an apex located immediately north of Mirandola. A set of (at least two) relatively small, north-verging detachment anticlines involves only the Neogene fine-grained sediments and are detached above the top of the carbonates, corresponding to the Scaglia Fm. (Figure 1b, c, Ths5). The Scaglia Fm. reflector is affected, with a small offset, by the thrust Th4 and back-thrust faults (Figure 1b, c), and is involved in a thrust-related anticline. Both the thrust fault and the anticline are well constrained by several wells tied to the seismic line (Camurana 2, San Felice sul Panaro 1, Spada 1, Bignardi 1, 1dir, and the wells in the Cavone oil field) (Figure 1c) and were described in fine detail in the hydrocarbon storage potential evaluation of the Rivara field (www. ERGRivarastorage.com). The second earthquake (Figure 1, T2) clearly occurred underneath the MirandolaSan Felice sul Panaro structural high. Ground deformation provided by DinSAR data (Figure 1a) also supports this interpretation, and in addition, the fringes distribution might suggest that two separate sources are responsible for the two main events (Fig. 1a, T1, T2).

This hypothesis, however, does not fit with the subsurface geology of the area that was reconstructed by seismic reflection profile interpretations and well data. Indeed, the thrust fault that affects the carbonate sequence and is responsible for the Mirandola-San Felice sul Panaro anticline remains shallower, as at least $3 \mathrm{~km}$ above the T2 hypocenter (10.2 $\mathrm{km}$ in depth), even though possible errors and uncertainties might derive from the regional velocity model for the hypocentral locations (ISIDe database) and from the time-to-depth conversion of the seismic profiles. Moreover, the curved attitude of the buried thrust fault is oblique with respect to the distribution of ground deformation achieved by the INSAR data, which are commonly elliptical for thrust faults with the long axis parallel to the trend of the fault.

In light of this evidence and these preliminary results, we suggest that the T1 event $(6.3 \mathrm{~km}$ in depth) originated along the Th2 buried thrust, and slipped along this fault (probably 


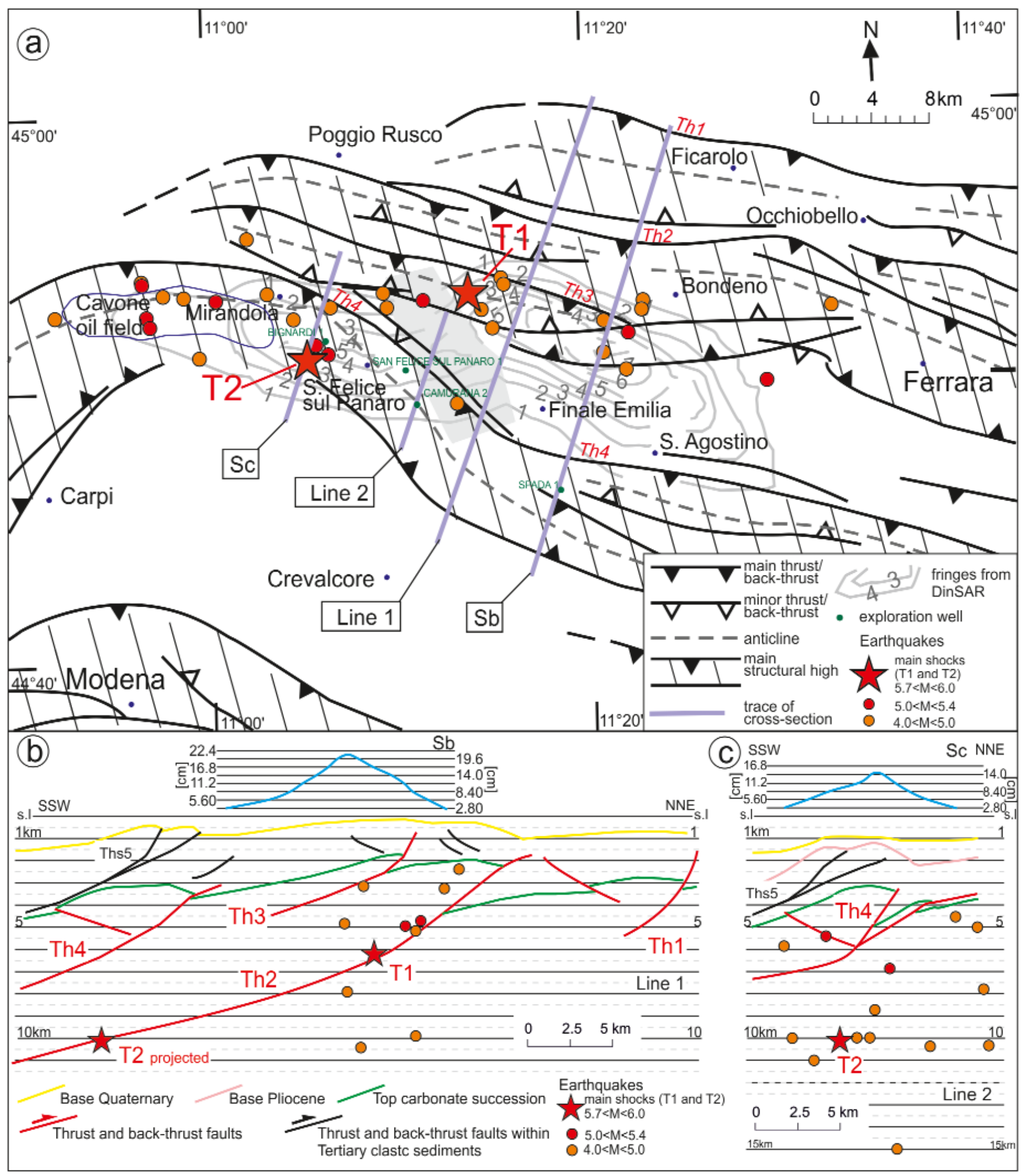

Figure 1. (a) Structural map of the western sector of the northern Apennines fold-and-thrust belt affected by the Emilia 2012 seismic sequence. The main events $(M>4)$ are located along the two main central ridges corresponding, from north to south, to the Ferrara-Bondeno-Poggio Rusco and the Mirandola-San Felice sul Panaro structures, respectively. Gray lines, fringes pattern obtained from the Radarsat- $1(1=5.6 \mathrm{~cm})$ interferogram [Atzori et al. 2012], showing the cumulative deformation from both the May 20, 2012, and the May 29, 2012, earthquakes (preseismic image of May 12, 2012, and postseismic image of June 12, 2012). The numbers indicate the progressive fringes used to calculate the total uplift across the epicentral area of the two main shocks (T1 and T2). (b, c) Schematic geological cross-sections (Line 1, Line 2) obtained from time-to-depth conversion of industrial seismic reflection profiles. The traces reported in (a) as line 2 is modified from the ERG GasStorage study. The hypocenters of the earthquakes within a strip of about $20 \mathrm{~km}$ of width and centered on the line trace are reported. Blue curves on top of the cross-sections, uplift in centimeters, obtained from the DinSAR data interpretation reported in (a). The deformation data were calculated along cross-sections where the ground deformation was maximal (see the traces $\mathrm{Sb}$ and $\mathrm{Sc}$ in (a)) and are projected parallel to the attitude of the thrust faults in the subsurface. 

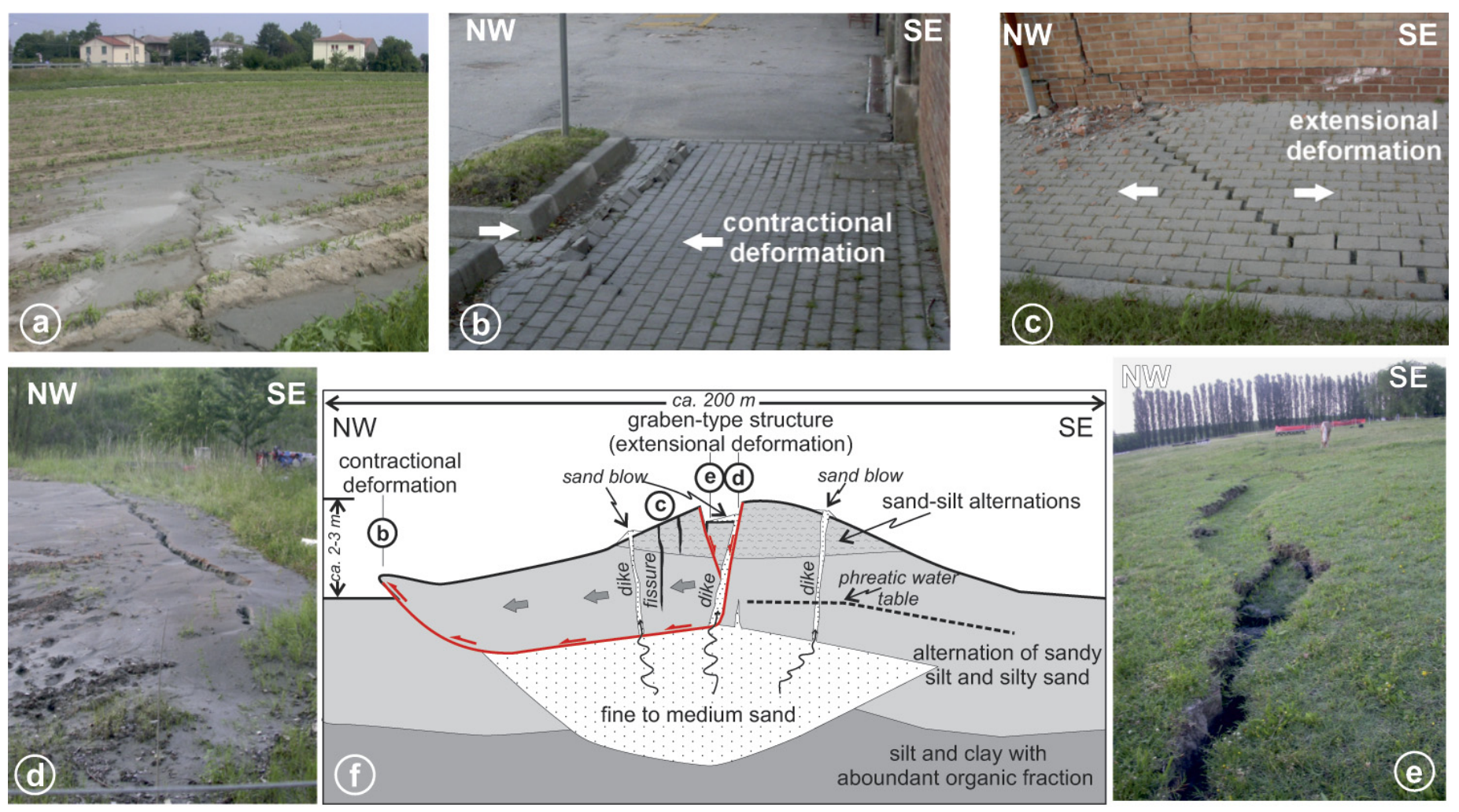

Figure 2. (a) Typical fissure with vented sand along the S. Martino Spino-Bondeno alignment. (b-e) Liquefaction features observed at the San Agostino cemetery, here interpreted as formed by lateral spreading along the NW-slope of a paleochannel/levee. (f) Possible interpretation of this (the schematic vertical section is not to scale). The stratigraphic sequence and depth to the water table are modified from Report Regione Emilia Romagna and DPC [2012].

with a prominent ESE-wards direction), but did not break the surface. This interpretation is also supported by the DinSAR fringes pattern, which are located in the back-limb/crestal zone of the thrust-related anticline (Figure 1a, b).

For the second event, we propose two alternative hypotheses:

1) The T2 event originated on a more westerly segment of the same Th2 thrust that underlies the FerraraBondeno-Poggio Rusco anticline. In such a case, it is possible that the entire Th2 structure is separated into two segments by a transverse fault zone that is NNE-SSW-striking, and is likely to be localized close to the T1 hypocenter. This hypothesis is in agreement with the bi-elliptical pattern of the coseismic ground deformation provided by the DinSAR analysis. Moreover, the occurrence of transverse Mesozoic structures in this zone has also been suggested by studies of subsurface data [Fantoni and Franciosi 2010]. This hypothesized transverse element, therefore, might represent a pre-existing cross-structure (inherited from preQuaternary tectonic phases) that acted as a segment barrier (in the sense of Pizzi and Galadini [2009]) during the rupture of the single fault segment.

2) the T2 event could be related to the Th3 thrust which runs parallel to the outermost thrust, but which ends towards the ESE, close to Finale Emilia. In this case, the thrust fault reported in Figure $1 \mathrm{~b}$ should deepen abruptly up to 10 $\mathrm{km}$ in depth in its southern part where, unfortunately, the seismic profile has poor resolution.

\section{Coseismic ground effects}

Two field survey campaigns conducted after the May 20, 2012, event (on May 24 and 28, 2012) and soon after the May 29, 2012, event allowed the detailed mapping of the coseismic ground effects observed in the epicentral areas. Although special care was taken to find evidence of primary coseismic thrust faulting, no conclusive evidence for surface faulting was observed in the field. This lack of evidence, however, is in agreement with the blind nature of the seismogenic source and it is supported by seismological and DinSAR analysis [Atzori et al. 2012].

However, although the main fault rupture did not reach the surface, the epicentral area showed secondary structures (induced by seismic shaking). These mostly consisted of a variety of liquefaction-related features (Figure 2), including fissures through which sediment was vented, and isolated sand-blows and fractures, and rarely craters. Excluding the particular case of the Sant'Agostino-Mirabello alignment (discussed later in this section), liquefaction features were extensively observed in very flat agricultural areas, which represented the Holocene alluvial lowlands. They generally consisted of long fissures, i.e., dike intersections with the ground surface, through which sand vented, forming beltlike linear sand bodies (Figure 2a). Individual fissures were commonly several meters long, but the alignment of enechelon fissures several tens of meters long was not unusual. Sediment vented to the surface typically consisted of bluishgrey silty-sand, sometimes with pieces of organic matter (a 


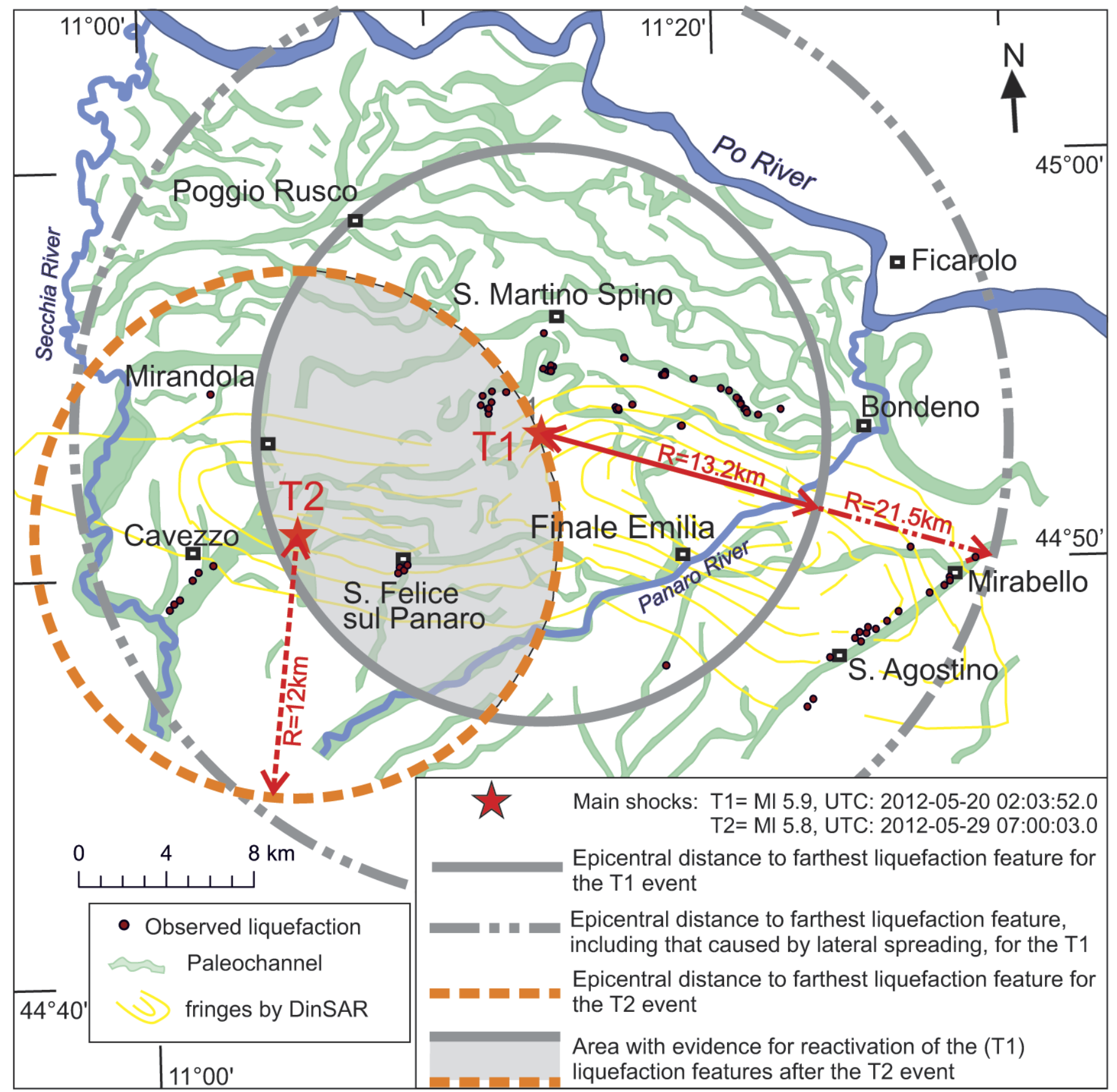

Figure 3. Map showing the distribution of the observed liquefaction features in the epicentral areas and their relationships with the courses of the paleochannels and the patterns of coseismic deformation by DinSAR analysis. Also shown: the liquefaction/ epicentral distance relation evaluated for the two main shocks (see text for explanation). Paleochannels pattern from R. Ferri (http://www.centuriazione.it/ quaderni_win.asp?id=69) and Manicardi [1991] (available at: http:/ / www.valledeidossi.it/territorio/geomorfologia.asp); DinSAR data [Atzori et al. 2012].

collected sample that we analyzed in the laboratory provided: silt $15 \%$, fine sand $70 \%$, and medium sand $15 \%$ ). Thicknesses of vented sediments of $0.15 \mathrm{~m}$ to $0.2 \mathrm{~m}$ were not unusual along the fissures, from where they tapered laterally with a slope angle of about $6^{\circ}$ to $10^{\circ}$. Statistical analysis of the fissure trend did not show any clear preferential orientations, although more than $70 \%$ of the strike data fall within the sector ranging from $\mathrm{N} 90^{\circ} \mathrm{E}$ to $\mathrm{N} 140^{\circ} \mathrm{E}$ (again, excluding the Sant'Agostino-Mirabello alignment).

However, it is of note that the earthquake-induced liquefaction phenomena were not radially distributed around the epicentral areas, but rather, they followed narrow, linear bands of en-echelon fissures and sand blows that corresponded very faithfully to the courses of prehistorical and historical-paleochannels (see Figure 3). Moreover, even though similar paleochannels have already been mapped in the whole epicentral area, most of these liquefaction alignments were concentrated relatively far from the epicenters (e.g., Figure 3, San Martino Spino-Bondeno alignment, Mirandola, Cavezzo).

A very clear $\mathrm{N} 50^{\circ}$ to $60^{\circ}$ orientation, however, characterizes the ca. 10-12 km long Sant'Agostino-Mirabello align- 
ment, where the most impressive liquefaction phenomena originated; i.e., the widest fissures, longest fractures, and largest volume of vented deposits. These occurred after the May 20, 2012, event, which also produced some severe damage to buildings and infrastructure in the urban areas. There were tens- to hundreds-of-meters-long linear fissures (Figure $2 \mathrm{c}$ ) parallel to the relief, and very large quantities of vented sand locally (Figure $2 \mathrm{~d}$ ), commonly showing several decimeters of downwarping accommodated by grabentype (extensional) structures near the crest of the relief (Figure 2e) and reverse (contractional) structures at the base of the slope (Figure $2 \mathrm{~b}$ ). These suggest that part of the shallower nonliquefiable units (sandy / silty alternations) moved to the NW, probably above the liquefied layer made of fine to medium sand of a deeper paleochannel facies, in response to lateral spreading (Figure $2 \mathrm{f}$ ). In this case, therefore, liquefaction susceptibility was greatly enhanced and mostly gravity driven, due to the relief with a very gentle slope (2\% to $3 \%)$, which corresponded to the paleochannel and levees of the Reno river.

Soon after the $M_{L} 5.8$ event of May 29, 2012, the revisiting of the sites that had liquefaction after the May 20, 2012, mainshock allowed the identification of those where 'reactivation' of liquefaction occurred and those where it did not. The measuring of the distance between (i) the May 20, 2012, epicenter and the related liquefaction features, and (ii) the May 29, 2012, epicenter and both the newly and reactivated liquefaction, allowed a better evaluation of the liquefaction/epicentral distance relationship for each main event, as schematized by the radii of the circles in Figure 3. The farthest liquefaction distances obtained (excluding the Sant' Agostino-Mirabello alignment) for the May 20 and 29, 2012, events are in good agreement with those provided by Obermeier [1996] for shallow ( $<50 \mathrm{~km})$ earthquakes with magnitudes around 5.8 to 6.0. Including the farthest distance of the Sant'Agostino-Mirabello alignment for the May 20, 2012, event (Figure 3, larger gray circle), instead, the value falls at the boundary of the curve limiting the field of the shallow earthquakes provided by Obermeier [1996].

\section{Discussion and conclusions}

Although a preliminary interpretation of the seismogenic sources has been discussed previously (see Section 3), we provide here a further discussion based on the results of coseismic ground effects presented above. The first point to note is: why did the rupture not break the surface? In agreement with the results provided by the available reports, indeed, the present study indicates the lack of evidence that the coseismic thrust faulting reached the ground surface, even though the magnitude values of the two main shocks (5.9 and 5.8) were just above the magnitude limit for surfacefaulting earthquakes [e.g., Wells and Coppersmith 1994]. Although detailed studies show that - in the mid-to-long term
- high subsidence and sedimentation rates are among the main factors that control the blind setting of the outer thrust fronts in the Po Plain [e.g., Carminati et al. 2003], these factors do not fully explain why during a single earthquake large enough to produce surface faulting, primary coseismic evidence is not observed at surface. Therefore, we suggest that two further possible causes can help to find an answer to this question. First, the Plio-Quaternary sequence of the Po Plain that overlies the Mesozoic-Cenozoic rocks consists of unconsolidated to poorly consolidated sediments with a thickness ranging from several hundreds of meters to a few kilometers. Therefore, such a geological setting provides strong attenuation as the displacement propagates upwards from seismogenic depths, as a result of strain absorption by intergranular shear. Secondly, if we consider the low-angle geometry of the seismogenic thrust source (as suggested in Section 3), then it is clear that a much larger ruptured area is required for the fault to reach the surface with respect to a high-angle fault (e.g., a high-angle reverse, back-thrust or normal fault). Based on the coseismic evidence for recent Italian earthquakes, we argue that similar magnitude earthquakes might be capable of surface faulting, like the M 6.0, Umbria-Marche 1997 earthquake, if the fault dip is $\geq 50^{\circ}$ to $60^{\circ}$ and a bedrock (lithified) fault plane was already exposed at, or very close to, the surface. Similarly, following the M 6.3, L'Aquila 2009 event, clear evidence for surface faulting away from the central sector of the Paganica fault was seen only at the Colle Enzano and Mount Stabiata localities [e.g., Falcucci et al. 2009, Boncio et al. 2010], just in correspondence with the local (along-strike) bedrock fault-plane exposure.

The second point comes from the evidence that the earthquake-induced liquefaction fissures (excluding the lateral spreading at the Sant'Agostino-Mirabello alignment) were: (i) frequently striking between E-W and NW-SE; and ii) not radially distributed away from the epicenters, but rather concentrated quite far from the epicenters. Based on this evidence, we suggest that although it is clear that there was primary control through the paleochannel pattern, also 'remote' tectonic control might have had a role in the location of the liquefaction. Moreover, it can be noted that most of these liquefaction alignments (e.g., San Martino Spino-Bondeno, Mirandola and Cavezzo) roughly corresponded to the outermost fringes detected by the interferometric analysis (Figure 3) at the boundary of the coseismically uplifted areas, and overlaying the crestal zone of the buried Th2 thrust-related anticline (Figure 1b). In this view, it can be argued that fissuring might have been favored by bending-moment extensional 'fracturing' [see Belabbès et al. 2009, and references] that developed coseismically by thrust-generated flexure above the growing anticline. Clearly, at present, these interpretations are only preliminary for which more detailed studies are definitely needed in the near future. 
Acknowledgements. We thank Francesca Cannarsa for fieldwork assistance. We thank the two anonymous reviewers and the journal editors for providing useful comments that helped us to improve the final manuscript. Seismic interpretations were carried out using Move and Kingdome Suite softwares. This study was funded by the MIUR (ex $60 \%$ - Pizzi and Scisciani) grants.

\section{References}

Atzori, S., J. Merryman Boncori, G. Pezzo, C. Tolomei and S. Salvi (2012). Secondo Report analisi dati SAR e modellazione della sorgente del terremoto dell'Emilia; ftp: / / ftpserver.rm.ingv.it/pub/cristiano.tolomei/Report_SAR_ INGV_Emilia_2.pdf

Belabbès, S., M. Meghraoui, Z. Çakir and Y. Bouhadad (2009). InSAR analysis of a blind thrust rupture and related active folding: the 1999 Ain Temouchent earthquake (Mw 5.7, Algeria) case study, J. Seismol., 13, 421-432.

Boccaletti, M., M. Coli, C. Eva, G. Ferrari, G. Giglia, A. Lazzarotto, F. Merlanti, R. Nicolich, G. Papani and D. Postpischl (1985). Considerations on the seismotectonics of the northern Apennines, Tectonophysics, 117, 7-38.

Boncio, P., A. Pizzi, F. Brozzetti, G. Pomposo, G. Lavecchia, D. Di Naccio and F. Ferrarini (2010). Coseismic ground deformation of the April 6th 2009 L'Aquila earthquake (central Italy, Mw 6.3), Geophys. Res. Lett., 37 L06308; doi:10.1029/2010GL042807.

Burrato, P., F. Ciucci and G. Valensise (2003). An inventory of river anomalies in the Po Plain, northern Italy: evidence for active blind thrust faulting, Annals of Geophysics, 46 (5), 865-882.

Carminati, E., C. Doglioni and D. Scrocca (2003). Apennines subduction-related subsidence of Venice (Italy). Geophys. Res. Lett., 30, 1717; doi:10.1029/2003GL017001.

CPTI Working Group (2011): http: / / emidius.mi.ingv.it/CPTI Devoti, R., A. Esposito, G. Pietrantonio, A.R. Pisani and F. Riguzzi (2011). Evidence of large-scale deformation patterns from GPS data in the Italian subduction boundary, Earth Planet. Sci. Lett., 311, 230-241; doi:10.1016/j.epsl. 2011.09.034.

DISS Working Group (2010). Database of Individual Seismogenic Sources (DISS), version 3.1.1: A compilation of potential sources for earthquakes larger than M 5.5 in Italy and surrounding areas; http: / / diss.rm.ingv.it/ diss / ERG GasStorage study: www. ERGRivarastorage.com

Falcucci, E., S. Gori, E. Peronace, G. Fubelli, M. Moro, M. Saroli, B. Giaccio, P. Messina, G. Naso, G. Scardia, A. Sposato, M. Voltaggio, P. Galli and F. Galadini (2009). The Paganica fault and surface coseismic ruptures due to the April 6, 2009 earthquake (L'Aquila, central Italy), Seismol. Res. Lett., 80, 940-950; doi:10.1785/gssrl.80.6.940.

Fantoni, R., and R. Franciosi (2010). Tectono-sedimentary setting of the Po Plain and Adriatic Foreland, Rend. Fis. Acc. Lincei, 21, S197-S209; doi:10.1007/s12210-010-0102-4.

Galli, P. (2000). Empirical relationships between magnitude and distance for liquefaction, Tectonophysics, 324, 169-187. Ghielmi, M., M. Minervini, C. Nini, S. Rogledi, M. Rossi and A. Vignolo (2010). Sedimentary and tectonic evolution in the eastern Po-Plain and northern Adriatic Sea area from Messinian to Middle Pleistocene (Italy), Rend. Fis. Acc. Lincei, 21, S131-S166; doi:10.1007/s12210-010-0102-4.

ISIDe (Italian Instrumental and Parametric Data-Base): http: / / iside.rm.ingv.it/iside/standard/index.jsp

Montone, P., M.T. Mariucci and S. Pierdominici (2012). The Italian present-day stress map, Geophys. J. Int. 189, 705-716.

Obermeier, S.F. (1996). Using liquefaction-induced features for paleoseismic analysis, In: J. McCalpin (ed.), Paleoseismology, New Academic Press, 331-396.

Pizzi, A., and F. Galadini (2009). Pre-existing cross-structures and active fault segmentation in the northern-central Apennines, Tectonophysics, 476, 302-319.

Regione Emilia Romagna and Eni-Agip (1988). Riserve idriche sotteranee della Regione Emilia Romagna, G. Di Dio (ed.), S.E.L.C.A., Firenze.

Report_DPC_1(2012): http:/ / www.protezionecivile.gov.it/ resources/cms / documents/ Report_DPC_1_Emilia_ EQSd.pdf

Report Regione Emilia Romagna and DPC (2012). Primo rapporto sugli effetti della liquefazione osservati a $S$. Carlo, frazione di S. Agostino (Provincia di Ferrara); http: / / ambiente.regione.emilia-romagna.it/geologia/ temi/sismica/liquefazione-gruppo-di-lavoro/ rapporto_ sancarlo.pdf

Scrocca, D., E. Carminati, C. Doglioni and D. Marcantoni (2007). Slab retreat and active shortening along the central-northern Apennines, In: O. Lacombe, J. Lavè, F. Roure and L. Verges (eds.), Thrust belts and foreland basins: From fold kinematics to hydrocarbon systems, Frontiers in Earth Sciences, 471-487.

Toscani, G., P. Burrato, D. Di Bucci, S. Seno and G. Valensise (2009). Plio-Quaternary tectonic evolution of the northern Apennines thrust fronts (Bologna-Ferrara section, Italy): seismotectonic implications, Ital. J. Geosci., 128, 605-613.

Wells, D.L., and K.J. Coppersmith (1994). New empirical relationships among magnitude, rupture length, rupture width, rupture area, and surface displacement, B. Seismol. Soc. Am., 84, 974-1002.

\footnotetext{
${ }^{\star}$ Corresponding author: Alberto Pizzi,

Università di Chieti-Pescara 'G. d'Annunzio', Dipartimento di Ingegneria e Geologia, Chieti, Italy; email: pizzi@unich.it.

C 2012 by the Istituto Nazionale di Geofisica e Vulcanologia. All rights reserved.
} 